\title{
Effect of Nutrient and Irrigation Levels on Nutrient Uptake, Water and Nutrient Use Efficiency, and Kapas Yield of Cotton in Southern Dry Zone of Karnataka
}

\author{
B.H. Prakash ${ }^{1}$, S.B. Yogananda ${ }^{\text {* }}$, B.G. Shekar ${ }^{2}$, S.S. Prakash ${ }^{1}$, \\ L. Vijay kumar ${ }^{1}$ and Mallikarjun ${ }^{2}$ \\ ${ }^{1}$ College of Agriculture, V. C. Farm, Mandya, Karnataka, India \\ ${ }^{2}$ Zonal Agricultural Research Station, V. C. Farm, Mandya, Karnataka, India \\ *Corresponding author
}

\begin{abstract}
A B S T R A C T
Keywords

Cotton, Irrigation, IW/CPE ratio,

Kapas, Lint,

Nutrient use

efficiency, Water

use efficiency

Article Info

Accepted:

12 January 2019

Available Online:

10 February 2019

A field experiment entitled "Effect of nutrient and irrigation levels on nutrient uptake, water and nutrient use efficiency, and kapas yield of cotton in Southern Dry Zone of Karnataka" was conducted during kharif 2016 at Zonal Agricultural Research Station, V. C. Farm, Mandya. The experiment was laid out in split plot design with 3 irrigation levels (0.6, 0.8 and 1.0 IW/CPE ratios) as main plots and 3 nutrient levels (75, 100 and 125\% RDF-150:75:75 kg NPK/ha) as sub plots, and these treatments were replicated thrice. Irrigation at $0.8 \mathrm{IW} / \mathrm{CPE}$ ratio and nutrient level of 100 per cent RDF have significantly recorded higher growth and yield parameters viz., plant height, sympodial branches, LAI, dry matter production, number of bolls plant ${ }^{-1}$, individual boll weight, harvest index, water and nutrient use efficiency, and lint yield along with the kapas yield (22.94 and $22.49 \mathrm{q}^{-} \mathrm{ha}^{-}$ ${ }^{1}$, respectively) as compared to irrigation at $0.6 \mathrm{IW} / \mathrm{CPE}$ ratio and nutrient level of 75 per cent RDF, respectively. But, they were at par with irrigation at $1.0 \mathrm{IW} / \mathrm{CPE}$ ratio and nutrient level of 125 per cent RDF, respectively and found optimum in enhancing the cotton growth and kapas yield.
\end{abstract}

\section{Introduction}

Cotton is popularly called as "White Gold" and is considered as "King of fiber crops". It is an important cash crop of global significance. Cotton plays a dominant role in the world agriculture and industrial economy. Cotton is an important raw material for the Indian textile industry and contributes at least 65 per cent of its requirements. Indian textile industry contributes significantly to the Indian economy by providing direct or indirect employment for about 60 million people in the country. In the world, cotton is being cultivated in an area of $31.5 \mathrm{~m}$ ha with a production of 106.3 million bales with an average productivity of $760 \mathrm{~kg} \mathrm{ha}^{-1}$. Cotton fulfills the 45 per cent of world fiber requirement.

India is the largest producer of cotton and contributes 25.4 per cent to the world cotton production. India has the largest area $(11.7 \mathrm{~m}$ ha) with 36.9 million bales production with an 
average productivity of $532 \mathrm{~kg} \mathrm{ha}^{-1}$ (Anon., 2016) in which the leading producer of cotton is Gujarat (125 lakh bales), followed by Maharastra (85 lakh bales), while, Tamil Nadu ranks first in productivity $(1214 \mathrm{~kg} / \mathrm{ha})$.

The productivity of cotton in India is low since 70 per cent of the cotton is grown under rainfed condition. Sankaranarayanan et al., (2004) revealed that the external supply of irrigation water to the cotton crop has increased the cotton yield tremendously as they have obtained 20 to 25 per cent higher seed cotton yield under irrigated condition over rainfed condition. External application of irrigation water along with the nutrients application will help in getting the increased yield. Application of the major nutrients such as $\mathrm{N}, \mathrm{P}$ and $\mathrm{K}$ had an effect over lint yield although most of the response was attributed to $\mathrm{N}$ (all cultivars) and to some extent $\mathrm{P}$. The results for all the quality factors suggest that $\mathrm{K}$ fertilization is a key to better quality (Kefyalew et al., 2007). The influence of optimum irrigation regime at different nutrient levels in sandy loam soils of Southern Dry Zone of Karnataka was found to be meager. Hence, the current investigation was conducted to optimize the irrigation regime, nutrient levels and their interaction for higher nutrient uptake, increased water and nutrient use efficiency and for higher kapas yield of cotton.

\section{Materials and Methods}

The field experiment was conducted during Kharif2016 in red sandy loam soil at Zonal Agricultural Research Station, V.C. Farm, Mandya. The soil of the experimental site was sandy loam in texture. The soil was neutral in soil reaction with a $\mathrm{pH}$ of 7.27 and normal in electrical conductivity $(0.38 \mathrm{dS} / \mathrm{m})$. The organic carbon content was 0.46 per cent and low in available $\mathrm{N}\left(210.54 \mathrm{~kg} \mathrm{ha}^{-1}\right)$, medium in available phosphorus $\left(27.48 \mathrm{~kg} \mathrm{ha}^{-1}\right)$ and available potassium $\left(152.20 \mathrm{~kg} \mathrm{ha}^{-1}\right)$. The experiment was laid out in split plot design with 3 irrigation levels (0.6, 0.8 and 1.0 IW/CPE ratios) as main plots and 3nutrientlevels (75, 100 and 125\% RDF$150: 75: 75 \mathrm{~kg} \mathrm{NPK} / \mathrm{ha}$ ) as sub plots, and these treatments were replicated thrice.

Cotton hybrid i.e., DCH-32 was used in the experiment, sown at a spacing of $90 \mathrm{~cm} \times 60$ $\mathrm{cm}$. The fertilizer application was done at the time of sowing, through soil application as per the treatments, in which 50 per cent of $\mathrm{N}$ and full dose of $\mathrm{P}$ and $\mathrm{K}$ were applied as basal dose. Remaining 50 per cent of $\mathrm{N}$ was top dressed in two splits at 50 DAS $(25 \% \mathrm{~N})$ and at 75 DAS $(25 \% \mathrm{~N})$. Irrigation was given by quantifying through water meter using the IW/CPE relation by fixing the IW (irrigation water) as $60 \mathrm{~mm}$ depth. Necessary plant protection measures were taken for the control of pests.

\section{Results and Discussion}

\section{Growth and yield parameters}

The experimental data (Table 1) indicates that the irrigation at $1.0 \mathrm{IW} / \mathrm{CPE}$ ratio recorded significantly higher plant height $(154.47 \mathrm{~cm})$ at 150 DAS, sympodial branches (20.11/plant) at harvest, leaf area index (3.43) at 120 DAS and dry matter production plant ${ }^{-1}$ (376.21 g/plant) at 120 DAS over irrigation at $0.6 \mathrm{IW} / \mathrm{CPE}$ ratio $(136.28 \mathrm{~cm}, 14.01 /$ plant, 2.58 and $296.19 \mathrm{~g} / \mathrm{plant}$, respectively). However, it was at par with irrigation at 0.8 IW/CPE ratio $(150.33 \mathrm{~cm}, 17.54 /$ plant, 3.15 and $347.47 \mathrm{~g} /$ plant, respectively).

Among the different nutrient levels, 125 per cent RDF recorded significantly higher plant height $(150.00 \mathrm{~cm})$ at 150 DAS, sympodial branches (19.23/plant) at harvest, leaf area index(3.31)at 120 DAS and dry matter production plant $^{-1}(372.27 \mathrm{~g} / \mathrm{plant})$ at 120 
DAS over 75 per cent of RDF $(135.35 \mathrm{~cm}$, 14.81/plant, 2.74 and $299.18 \mathrm{~g} /$ plant, respectively). However, it was at par with 100 per cent of RDF (145.73 cm, 17.63/plant, 3.11 and $348.42 \mathrm{~g} /$ plant, respectively). These results are in line with the findings of Srinivasan and Aananthi (2017) and Yang et al., (2015).

The data presented in Table 2 indicates that the irrigation at 1.0 IW/CPE ratio recorded significantly higher number of bolls per plant (55.55) at harvest, individual boll weight (4.7 g) and harvest index (0.42) over irrigation at $0.6 \mathrm{IW} / \mathrm{CPE}$ ratio (40.04/plant, $4.13 \mathrm{~g}$ and 0.35 , respectively).

However, it was at par with irrigation at 0.8 IW/CPE ratio (52.47/plant, 4.52 and 0.41 , respectively).

Among the different nutrient levels, 125 per cent RDF ratio recorded significantly higher number of bolls per plant (52.23/plant) at harvest, individual boll weight (4.72 g) and harvest index (0.41) over 75 per cent RDF (45.49/plant, 4.20 and 0.36, respectively). However, it was at par with 100 per cent of RDF (49.33/plant, 4.51 and 0.41 , respectively). This was due to higher frequency of irrigation, which led to better availability and uptake of nutrients as well as their partition to different parts. These results are in line with the findings of Srinivasan and Aananthi (2017), Yang et al., (2015), Alse and Jadhav (2011).

Increase in growth attributes was also due to higher quantity of nutrients coupled with good available moisture leading to better uptake and partition. In addition, nitrogen has crucial role in cell division and elongation there by increased the plant height, phosphorus might have influenced better root growth there by increased uptake of nutrients and water. Better phosphorus management helps in diversion of plant metabolites towards the developing buds, flowers and bolls, and also the translocation of more photosynthates towards the sink and consequent development of yield attributes as reported by Seema et al., (2012). Higher quantity of nutrient supply at the initial stages is also one of the reasons for enhanced growth parameters. These results also agree with the findings of Gundluret al., (2013), Mandeep Kumar et al., (2011), Ghongane et al., (2009), Kalaichelvi, (2009) and Pettigrew, (2004).

There was no significant difference in plant height, monopodial branches, sympodial branches and dry matter production due to combined effect of nutrient and irrigation levels. These results are in line with the findings of Gundlur et al., (2013).

\section{Kapas and lint yield}

Different nutrient and irrigation levels had a significant effect on kapas and lint yield of cotton (Table 2). Irrigation at 1.0 IW/CPE ratio recorded significantly higher kapas and lint yield of cotton (24.37 and $8.69 \mathrm{q} / \mathrm{ha}$, respectively) over irrigation at $0.6 \mathrm{IW} / \mathrm{CPE}$ ratio (15.91 and $5.25 \mathrm{q} / \mathrm{ha}$, respectively). However, it was at par with irrigation at 0.8 IW/CPE ratio (22.94 and $8.12 \mathrm{q} / \mathrm{ha}$, respectively).

Among the different nutrient levels, 125 per cent RDF recorded significantly higher kapas and lint yield of cotton $(23.55$ and $8.35 \mathrm{q} / \mathrm{ha}$, respectively) over 75 per cent RDF (17.18 and 5.83, respectively). However, it was at par with 100 per cent of RDF (22.49 and 7.88 $\mathrm{q} /$ ha, respectively).

Increase in kapas and lint yield was due increased growth parameters, yield attributes and drymatter production, as well as its partition to different parts due to combined effect of N, P and $\mathrm{K}$ with frequent irrigations. Higher sympodial branches leading to higher 
boll number and boll weight might have enhanced seed cotton yield (kapas).

The leaf growth continued even atboll development stage and higher dry matter accumulation in the fruiting bodies at the later stages of the crop growth were also the reason for higher yield.

These results are in conformity with the findings of Deepa and Aladakatti (2016), Amandeep et al., (2015), Jat et al., (2014), Shukla et al., (2014), Gundlur et al., (2013), Amandeep et al., (2013).

\section{Nutrient uptake}

Nitrogen, phosphorus and potassium uptake were significantly influenced by different irrigation levels. Among them, higher uptake (111.64, 15.63 and $99.82 \mathrm{~kg} / \mathrm{ha}$, respectively) was recorded with the irrigation at IW/CPE ratio of 1.0 compared to irrigation at IW/CPE ratio of $0.6(73.52,11.90$ and $59.21 \mathrm{~kg} / \mathrm{ha}$, respectively). However, it was at par with irrigation at IW/CPE ratio of 0.8 (106.63, 14.95 and $96.10 \mathrm{~kg} / \mathrm{ha}$, respectively) (Table $3)$.

Table.1 Effect of nutrient and irrigation levels on growth and yield parameters of cotton

\begin{tabular}{|c|c|c|c|c|}
\hline \multirow[t]{2}{*}{ Treatment } & \multicolumn{4}{|c|}{ Growth and yield parameters } \\
\hline & $\begin{array}{l}\text { Plant height } \\
(\mathrm{cm}) \text { at } 150 \\
\text { DAS }\end{array}$ & $\begin{array}{c}\text { Sympodial } \\
\text { branches }^{-1} \text { at } \\
\text { plant }^{-1} \text { at } \\
\text { harvest }^{-}\end{array}$ & $\begin{array}{l}\text { LAI at } 120 \\
\text { DAS }\end{array}$ & $\begin{array}{l}\text { Dry matter } \\
\text { production } \\
\text { plant }^{-1}(\mathrm{~g}) \text { at } \\
120 \text { DAS }\end{array}$ \\
\hline \multicolumn{5}{|c|}{ Irrigation levels } \\
\hline$I_{1}: I W / C P E=0.6$ & 136.28 & 14.01 & 2.58 & 296.19 \\
\hline$I_{2}: I W / C P E=0.8$ & 150.33 & 17.54 & 3.15 & 347.47 \\
\hline$I_{3:} I W / C P E=1.0$ & 154.47 & 20.11 & 3.43 & 376.21 \\
\hline SEm. \pm & 1.97 & 0.68 & 0.14 & 7.97 \\
\hline C.D.@ $9 \%$ & 7.73 & 2.65 & 0.54 & 31.21 \\
\hline \multicolumn{5}{|c|}{ Nutrient levels } \\
\hline$F_{1}: 75 \%$ RDF & 135.35 & 14.81 & 2.74 & 299.18 \\
\hline $\mathrm{F}_{2}: 100 \% \mathrm{RDF}$ & 145.73 & 17.63 & 3.11 & 348.42 \\
\hline $\mathrm{F}_{3}: 125 \% \mathrm{RDF}$ & 150.00 & 19.23 & 3.31 & 372.27 \\
\hline SEm. \pm & 1.85 & 0.66 & 0.09 & 7.23 \\
\hline C.D. @ 5\% & 7.26 & 2.58 & 0.35 & 28.31 \\
\hline \multicolumn{5}{|c|}{ Irrigation levels $\times$ Nutrient levels } \\
\hline $\begin{array}{l}\text { S. Em. } \pm \text { (Between sub plots } \\
\text { at same mainplot) }\end{array}$ & 3.56 & 1.07 & 0.23 & 12.65 \\
\hline $\begin{array}{l}\text { C. D. }(p=0.05) \text { (Between sub } \\
\text { plots at same main plot) }\end{array}$ & NS & NS & NS & NS \\
\hline $\begin{array}{l}\text { S. Em. } \pm \text { (Between main } \\
\text { plots at same or different } \\
\text { sub plots) }\end{array}$ & 1.01 & 0.94 & 0.47 & 2.49 \\
\hline $\begin{array}{l}\text { C. D. }(p=0.05) \text { (Between } \\
\text { main plots at same or } \\
\text { different sub plots) }\end{array}$ & NS & NS & NS & NS \\
\hline
\end{tabular}


Table.2 Effect of nutrient and irrigation levels on yield parameters and yield of cotton

\begin{tabular}{|c|c|c|c|c|c|}
\hline \multirow[t]{2}{*}{ Treatment } & \multicolumn{5}{|c|}{ Growth and yield parameters } \\
\hline & $\begin{array}{l}\text { Number of } \\
\text { bolls per } \\
\text { plant }\end{array}$ & $\begin{array}{l}\text { Individual } \\
\text { boll weight } \\
\text { (g/boll) }\end{array}$ & $\begin{array}{l}\text { Harvest } \\
\text { index }\end{array}$ & $\begin{array}{c}\text { Kapas } \\
\text { yield } \\
\text { (q/ha) }\end{array}$ & $\begin{array}{l}\text { Lint yield } \\
\text { (q/ha) }\end{array}$ \\
\hline \multicolumn{6}{|c|}{ Irrigation levels } \\
\hline$I_{1}: I W / C P E=0.6$ & 40.04 & 4.13 & 0.35 & 15.91 & 5.25 \\
\hline$I_{2}: I W / C P E=0.8$ & 52.47 & 4.52 & 0.41 & 22.94 & 8.12 \\
\hline$I_{3:} \mathrm{IW} / \mathrm{CPE}=1.0$ & 55.55 & 4.70 & 0.42 & 24.37 & 8.69 \\
\hline SEm. \pm & 1.96 & 0.08 & 0.01 & 0.43 & 0.21 \\
\hline C.D.@5\% & 7.65 & 0.32 & 0.02 & 1.69 & 0.81 \\
\hline \multicolumn{6}{|c|}{ Nutrient levels } \\
\hline $\mathrm{F}_{1}: 75 \% \mathrm{RDF}$ & 45.49 & 4.20 & 0.36 & 17.18 & 5.83 \\
\hline $\mathrm{F}_{2}: 100 \% \mathrm{RDF}$ & 49.33 & 4.51 & 0.41 & 22.49 & 7.88 \\
\hline $\mathrm{F}_{3}: 125 \% \mathrm{RDF}$ & 52.23 & 4.72 & 0.41 & 23.55 & 8.35 \\
\hline SEm. \pm & 0.94 & 0.06 & 0.01 & 0.83 & 0.25 \\
\hline C.D. @ 5\% & 3.67 & 0.24 & 0.03 & 3.25 & 0.97 \\
\hline \multicolumn{6}{|c|}{ Irrigation levels $\times$ Nutrient levels } \\
\hline $\begin{array}{l}\text { S. Em. } \pm(\text { Between sub } \\
\text { plots at same main plot })\end{array}$ & 1.99 & 0.11 & 0.03 & 2.70 & 0.89 \\
\hline $\begin{array}{l}\text { C. D. }(p=0.05) \text { (Between } \\
\text { sub plots at same main } \\
\text { plot) }\end{array}$ & NS & NS & NS & NS & NS \\
\hline $\begin{array}{l}\text { S. Em. } \pm \text { (Between main } \\
\text { plots at same or different } \\
\text { sub plots) }\end{array}$ & 1.37 & 0.17 & 0.13 & 1.50 & 0.86 \\
\hline $\begin{array}{l}\text { C. D. }(p=0.05) \text { (Between } \\
\text { main plots at same or } \\
\text { different sub plots) }\end{array}$ & NS & NS & NS & NS & NS \\
\hline
\end{tabular}


Table.3 Effect of nutrient and irrigation levels on nutrient uptake, water use efficiency (WUE) and nutrient use efficiency (NUE)

\begin{tabular}{|c|c|c|c|c|c|}
\hline Treatment & $\begin{array}{c}\text { Nuptake } \\
\text { (kg/ha) }\end{array}$ & $\begin{array}{c}\text { Puptake } \\
\text { (kg/ha) }\end{array}$ & $\begin{array}{l}\text { Kuptake } \\
\text { (kg/ha) }\end{array}$ & $\begin{array}{l}\text { WUE } \\
(\mathrm{kg} / \mathrm{ha}- \\
\mathrm{cm})\end{array}$ & $\begin{array}{c}\text { NUE } \\
(\mathrm{kg} / \mathrm{kg} / \mathrm{ha})\end{array}$ \\
\hline \multicolumn{6}{|c|}{ Irrigation levels } \\
\hline$I_{1}: I W / C P E=0.6$ & 73.52 & 11.90 & 59.21 & 41.00 & 5.39 \\
\hline $\mathrm{I}_{2}: \mathrm{IW} / \mathrm{CPE}=0.8$ & 106.63 & 14.95 & 96.10 & 50.30 & 7.78 \\
\hline$I_{3:} I W / C P E=1.0$ & 111.64 & 15.63 & 99.82 & 41.90 & 8.24 \\
\hline SEm. \pm & 3.01 & 0.32 & 1.38 & 1.10 & 0.17 \\
\hline C.D. @ 5\% & 11.77 & 1.27 & 5.41 & 4.20 & 0.68 \\
\hline \multicolumn{6}{|c|}{ Nutrient levels } \\
\hline $\mathrm{F}_{1}: 75 \% \mathrm{RDF}$ & 87.80 & 12.86 & 75.77 & 36.30 & 7.63 \\
\hline $\mathrm{F}_{2}: 100 \% \mathrm{RDF}$ & 99.50 & 14.29 & 86.74 & 47.30 & 7.50 \\
\hline $\mathrm{F}_{3}: 125 \%$ RDF & 104.49 & 15.32 & 92.63 & 49.60 & 6.28 \\
\hline SEm. \pm & 2.29 & 0.29 & 2.17 & 1.20 & 0.20 \\
\hline C.D. @ 5\% & 8.96 & 1.15 & 8.51 & 4.70 & 0.80 \\
\hline \multicolumn{6}{|c|}{ Irrigation levels $\times$ Nutrient levels } \\
\hline $\begin{array}{l}\text { S. Em. } \pm \text { (Between sub plots } \\
\text { at same main plot) }\end{array}$ & 3.86 & 0.60 & 2.68 & 5.20 & 0.88 \\
\hline $\begin{array}{l}\text { C. D. }(p=0.05) \text { (Between sub } \\
\text { plots at same main plot) }\end{array}$ & NS & NS & NS & NS & NS \\
\hline $\begin{array}{l}\text { S. Em. } \pm \text { (Between main plots } \\
\text { at same or different sub } \\
\text { plots) }\end{array}$ & 1.61 & 0.53 & 0.95 & 6.40 & 0.86 \\
\hline $\begin{array}{l}\text { C. D. ( } p=0.05 \text { ) (Between main } \\
\text { plots at same or different sub } \\
\text { plots) }\end{array}$ & NS & NS & NS & NS & NS \\
\hline
\end{tabular}

Among the different nutrient levels, significantly higher nitrogen, phosphorus and potassium uptake (104.49, 15.32 and 92.63 $\mathrm{kg} / \mathrm{ha}$, respectively) was recorded with the nutrient level of 125 per cent RDF compared to 75 per cent RDF $(87.80,12.86$ and 75.77 $\mathrm{kg} / \mathrm{ha}$, respectively). However, it was at par with 100 per cent RDF (99.50, 14.29 and $86.74 \mathrm{~kg} / \mathrm{ha}$, respectively). There was a nonsignificant effect on nutrient uptake due to the combined effect of nutrient and irrigation levels. These results are in conformity with the findings of Bhalerao et al., (2011). 


\section{Water use efficiency (WUE)}

The water use efficiency was significantly higher $(50.3 \mathrm{~kg} / \mathrm{ha}-\mathrm{cm})$ with the irrigation at IW/CPE ratio of 0.8 as compared to irrigation at IW/CPE ratio of 0.6 and IW/CPE ratio of 1.0 (41.0 \& $41.9 \mathrm{~kg} / \mathrm{ha}-\mathrm{cm}$, respectively). However, the latter two irrigation levels were on par with each other. Nutrient level of 125 per cent RDF had recorded significantly higher WUE (49.6 kg/ha-cm) compared to 75 per cent RDF (36.3 kg/ha-cm). However, it was at par with 100 per cent RDF (47.3 $\mathrm{kg} / \mathrm{ha}-\mathrm{cm})$. There was a non-significant effect on WUE due to combined effect of nutrient and irrigation levels. These results are in line with the findings of Bhalerao et al., (2011).

\section{Nutrient use efficiency (NUE)}

Irrigation at IW/CPE ratio of 1.0 recorded significantly higher NUE $(8.24 \mathrm{~kg} / \mathrm{kg} / \mathrm{ha})$ compared to irrigation at IW/CPE ratio of 0.6 $(5.39 \mathrm{~kg} / \mathrm{kg} / \mathrm{ha})$. However, it was at par with irrigation at IW/CPE ratio of 0.8 (7.78 $\mathrm{kg} / \mathrm{kg} / \mathrm{ha}$ ). Nutrient level of 75 per cent RDF had recorded significantly higher nutrient use efficiency $(7.63 \mathrm{~kg} / \mathrm{kg} / \mathrm{ha})$ compared 125 per cent RDF (6.28 kg/kg/ha). However, it was at par with 0.8 IW/CPE irrigation level $(7.50 \mathrm{~kg} / \mathrm{kg} / \mathrm{ha})$. There was no significant difference due to interaction effect of nutrient and irrigation levels. Similar results were also reported by Gundlur et al., (2013).

The present experiment revealed that irrigating the cotton at IW/CPE ratio of 0.8 is found optimum and recorded significantly higher seed cotton yield, water use efficiency and nutrient use efficiency (22.94 q/ha, 50.30 $\mathrm{kg} / \mathrm{ha}-\mathrm{mm}$ and $7.78 \mathrm{~kg} / \mathrm{kg} / \mathrm{ha}$, respectively) similar to that of irrigation at $1.0 \mathrm{IW} / \mathrm{CPE}$ ratio. Application of 100 per cent RDF (150:75:75 kg NPK/ha) is found optimum and recorded significantly higher seed cotton yield, water use efficiency and nutrient use efficiency $(22.49 \mathrm{q} / \mathrm{ha}, 47.30 \mathrm{~kg} / \mathrm{ha}-\mathrm{mm}$ and $7.50 \mathrm{~kg} / \mathrm{kg} / \mathrm{ha}$, respectively) similar to that of 125 per cent RDF.

\section{References}

Alse, U. N. and Jadhav, A. S., 2011. Agronomic efficacy of $B t$ and non $B t$ cotton hybrids under irrigated conditions. Journal of Cotton Research and Development. 25(1): 38-41.

Amandeep, S. B., Sarlach, R. S. and Rathore, P., 2015. Response of desicotton (Gossypium arboretum L.) hybrids to spacing and fertilizer levels under irrigated conditions. Journal of Cotton Research and Development. 29(1): 7980.

Amandeep, S. B., Sarlach, R. S., Sohu, R. S. and Pankaj, R., 2013.Response of American cotton (Gossypium hirsutum L.) genotypes to varying plant densities and graded levels of fertilizers.Vegetos.26(2): 145-147.

Bhalerao, P. D., Gaikwad G. S. andImade, S. R., 2011.Productivity and nutrient uptake of Bt-cotton (Gossypium hirsutum) as influenced by precision in application of irrigation and fertilizer. Indian Journal of Agronomy. 56(2): 150-153.

Deepa, G. S. and Aladakatti, Y. R., 2016.Effect of nutrient levels and split application of nitrogen and potassium on yield, economics and fibre quality parameters of interspecific $B t$ cotton. Journal of Farm Sciences. 29(2): 203207.

Ghongane, S. B., Yeledhalli, N. A., Ravi, M.V., Patil, B.V., Desai, B. K. and Beledhadi, R. V., 2009. Effect of fertilizer and irrigation levels on growth, yield and quality of transgenic $B t$ cotton in deep vertisols. Karnataka Journal of Agricultural Sciences. 22(4): 905-908. 
Gundlur, S. S., Rajkumara, S., Neelakanth, J. K., Ashoka, P. and Khot, A. B., 2013.Water and nutrient requirement of $B t$ cotton under vertisols of Malaprabha command. Karnataka Journal of Agricultural Sciences. 26(3): 368-371.

Jat, R. D., Nanwal, R. K., Pawan, K. andShivran, A. C., 2014. Productivity and nutrient uptake of $B t$ cotton (Gossypium hirsutum L.) under different spacing and nutrient level. Journal of Cotton Research and Development. 28(2): 260-262.

Kalaichelvi, K., 2009, Bt cotton response to plant geometry and fertilizer levels. Journal of Cotton Research and Development. 23(2): 96-99.

Kefyalew, G., Roger, K. T., Kyle, W. F., Randal, K. B. and William, R. R., 2007. Cotton lint yield and quality as affected by applications of $\mathrm{N}, \mathrm{P}$, and $\mathrm{K}$ fertilizers. Journal of Cotton Sciences.11: 12-19.

Mandeepkumar, Pannu, R. K., Nehra, D. S. and Dhaka, A. K., 2011. Effect of spacing and fertilizer on growth, yield and quality of different cotton genotypes. Journal of Cotton Research and Development. 25(2): 236-239.

Pettigrew, W. T., 2004. Moisture deficit effects on cotton lint yield, yield components, and boll distribution. Agronomy Journal. 96: 377-383
Sankaranarayanan, K., Nalayini, P. and Praharaj, C. S., 2004. Agronomic requirements of $B t$ cotton hybrid in relation to plant densities and fertilizer requirement. International Symposium on Strategies and Sustainable Cotton Production- A Global Vision, University of Agricultural Sciences, Dharwad, pp. 23-25.

Seema, S., Ahlawat, I. P. S. and Rana, D. S., 2012. Effect of phosphorus sources and levels on Bt-cotton (Gossypium hirsutum) based intercropping systems. Indian Journal of Agronomy. 57(3): 235-240.

Shukla, U. N., Bhale, V. M., Wanjari, S. S. and Khadse, V. A. 2014. Production potential and economics of cotton (Gossypium hirsutum) hybrids under different plant spacing and NPK levels. Indian Journal of Agronomy. 59(4): 668-671.

Srinivasan, G. and Aananthi, N. 2017. Effect of moisture stress management practices on growth, yield and quality of $G$. hirsutum cotton. Journal of Cotton Research and Development. 31(1): 8286.

Yang, C., Luo, Y., Sun, L. and Wu, N. 2015. Effect of deficit irrigation on the growth, water use characteristics and yield of cotton in arid Northwest China. Pedosphere. 25(6): 910-924.

\section{How to cite this article:}

Prakash, B.H., S.B. Yogananda, B.G. Shekar, S.S. Prakash, L. Vijay Kumar and Mallikarjun. 2019. Effect of Nutrient and Irrigation Levels on Nutrient Uptake, Water and Nutrient Use Efficiency, and Kapas Yield of Cotton in Southern Dry Zone of Karnataka. Int.J.Curr.Microbiol.App.Sci. 8(02): 1556-1563. doi: https://doi.org/10.20546/ijcmas.2019.802.182 